\title{
A Model to Improve the Implementation Standards of Street Lighting Based on Solar Energy: A Case Study
}

\author{
Wahyudi Sutopo ${ }^{1,2, * \mathbb{D}}$, Ika Shinta Mardikaningsih ${ }^{1}$, Roni Zakaria ${ }^{1}$ and Ahad Ali ${ }^{3}$ \\ 1 Laboratory of Business and Logistic System, Industrial Engineering Department, Faculty of Engineering, \\ Universitas Sebelas Maret, Ir. Sutami Rd. No. 36A, Surakarta 57126, Indonesia; \\ ikashinta2012@gmail.com (I.S.M.); ronny01@runbox.com (R.Z.) \\ 2 National Center for Sustainable Transportation Technology, Bandung 40132, Indonesia \\ 3 Leon Linton Department of Mechanical Engineering, Lawrence Technological University, \\ Southfield, MI 48075, USA; sali@ltu.edu \\ * Correspondence: wahyudisutopo@staff.uns.ac.id
}

Received: 6 December 2019; Accepted: 21 January 2020; Published: 3 February 2020

\begin{abstract}
This paper aims to improve the implementation standards of solar-energy-based street lighting in Indonesia. A model framework was developed to assess existing conditions regarding the level of lux, the distance between poles, pole height, and lamp power. According to the evaluation of the existing circumstances, the street lighting system is not satisfactory according to the national standard, with $64.7 \%$ black area. An alternative installation of street lighting designed by DIALux application was proposed to fulfill the technical standard of street lighting. The result shows that this alternative design can be used for renewing existing street lighting with better performance and reliability. Economic analysis of all technically feasible alternatives was conducted afterward by benefit-cost analysis. The analysis shows that solar-energy-based street lighting requires as much as $621,473,620.00$ Indonesian Rupiah (IDR), with 1.06 benefit-cost ratios and a 9\% reduction of total cost. Therefore, the analysis indicates that solar-energy-based technology can be feasibly implemented in a street lighting system. The results show that the proposed model can be applied to improve the implementation standard of solar-energy-based street lighting.
\end{abstract}

Keywords: economic analysis; national standard; solar-energy-based technology; street lighting

\section{Introduction}

Batteries are classified as primary and secondary batteries [1]. A primary lithium battery is an un-rechargeable battery with lithium metal elements as the anode. The primary cell is commonly used in watches, calculators, and other electronic devices. A secondary lithium battery is a rechargeable battery that is usually found in consumer electronic products such as notebooks, personal computers, smartphones, electric bikes, street lighting, and many other electronic gadgets [2].

Street lighting is an essential part of most facilities. However, high operating costs, improper illumination levels, and inefficient power are usually experienced with respect to street lighting installation systems. The lighting quality of a particular street is influenced by several factors such as street type, street width, pole height, the distance between poles, and the type of lamp being used according to the National Standard of Indonesia (NSI) (NSI 7931:2008) [3]. The quality is indicated by the illumination level in certain areas [3].

There are papers about the study of the techno-economy of public street lightings by various authors, such as Velaga and Kumar [4], Kusumayogo et al. [5], Sihombing and Kasim [6], and Jamil et al. [7]. Ahmad [8] and Al-Salaymeh et al. [9] studied the technical and economic assessment of photovoltaic in residential buildings. Ramadhan and Naseeb [10] studied the cost-benefit analysis of implementing 
a photovoltaic solar system. Kannan et al. [11] presented a life cycle assessment study of a solar photovoltaic system. Reid and Wynn [12] studied the future of solar power in the United Kingdom and calculated its economic impacts. Escolar et al. [13] sought to improve the quality of street lighting in Spain. Cellucci et al. [14] studied smart lighting in a small town. Salata et al. [15] made an economic and investment assessment of safety and emergency lighting in road tunnels. However, previous methods have not been able to perform a real case study analysis of the techno-economic feasibility of solar energy while considering the NSI [3] regarding street lighting specifications in urban areas.

The Faculty of Engineering in Universitas Sebelas Maret is a campus area that has a public institution that provides street lighting facilities. A case study in this research was held on this campus. There are 17 lighting points spread on the street surrounding the faculty. Evaluation of the provided facility shows that $64.7 \%$ is black area. In other words, the system does not suit the national standard. In light of this issue, a new installation of lighting needs to be designed.

NSI 7391:2008 regarding "Street Lighting Specification in Urban Area" was used as the standard reference in the design process of the new lighting system. Several aspects to be considered in the design process were lighting quality, used material, energy source, and the installation type. DIALux 4.12 is software that can assist in the process, especially in lighting quality improvement. DIALux 4.12 can simulate natural and artificial light and can update continuously. DIALux 4.12 also offers a balanced combination of technical analysis and graphical results that make it appropriate $[16,17]$. This software can be applied not only to street lighting but also to long road tunnel lighting simulation [18].

As Indonesia has massive potential in solar energy $[19,20]$, alternative energy resources can be exploited. An example of solar energy utilization is solar-energy-based street lighting. Universitas Maret University, a "green campus," has begun to develop new street lighting technology with more environment-friendly energy-solar energy. Besides a technical assessment, examining the implementation of the latest technology requires investment feasibility analysis. The full review can be summarized in two stages of evaluation, the technical aspect and the economic aspect, and the efficiency level can also be compared to conventional electric resources.

\section{Materials and Methods}

Street lighting is part of a complementary structure of roads that can be placed or installed on the left or right side of the road and/or in the middle (in the middle part of the road) and is intended to brighten the path or neighborhood around the required road, including crossroads, bridges, and underground roads [21]. The components of a complete street lighting construction consist of a light source, an optical element, an electrical element, a support structure, and a light pole foundation [22].

Street lighting in this area is spread throughout the campus area. The lighting of public roads in the campus environment is divided into two types, namely, main public road lighting and solar-based street lighting support. The difference between these two types of illumination lies in the function and the type of lamp used. The main street lighting serves as the lighting on the main road of the campus, while the solar-based street lighting support serves as street lighting and illuminates locations or buildings in the campus environment.

In this study, the number of main street lighting points was 74 units. Public road lighting that exists on-campus still entirely employs electrical energy, sourced from the State Electricity Company Indonesia (PLN, Perusahaan Listrik Negara). This makes it suitable as a case study in investigating the application of solar-powered public lighting.

Street lighting with solar energy as the source of energy is an energy-saving alternative [23]. As the energy comes from the sun, the operational cost of the street lighting is cheap and economical [24]. Solar street light lighting uses solar cell panels that receive sunlight and convert it into energy through a photovoltaic process [25]. The illuminations can work automatically, with lights that go on at night and go out in the morning, with easy and inexpensive maintenance. The street lighting of the solar powerhouse itself consists of several components, namely solar cell panels, LED lights, lamp posts, and battery boxes [26]. 
The source of solar street light energy comes from the light of the sun, which is then absorbed by the solar cell panel. According to Markvart et al. [27], the process of solar cell panels starts by converting the sunlight into a DC current, which is then stored inside the battery. Before being stored in the battery, there is a device that acts as an energy flow controller, and this tool regulates a system that works on a common solar street lighting called a controller. The controller is given times when the lights must be on and when the lights must be off; there is also a system that regulates when the battery should be charged. Next, to set the battery management system, there is a tool called a battery management system (BMS) that serves to cut off and discharge the battery [28].

The lifetime of the solar cell panel is 25 years old [29,30]. For an LED lamp with 50,000 h of life, if the lights are on for $12 \mathrm{~h}$ every day, then the lamp can operate for 11 years [31,32], and this lifetime can be compared with conventional solar-based street lighting, which the State Electricity Company still employs. So far, solar street lighting has proven advantages over conventional street lighting [33], but the application of solar-powered public road lighting is restricted by weather constraints and high investment costs. Therefore, in this research, the utilization of solar-based public lighting will be analyzed in depth, particularly on the feasibility of the investment to overcome these problems.

\subsection{The Standard Components of Solar-Based Street Lighting}

Several components in solar-based street lighting are used in the planning and designing of the primary construction of solar public road lighting. These elements include solar cell panels, lamps, LED lights, street lighting poles, and battery panel boxes.

- Solar Cell Panels

The solar cell panel is an electronic component that can convert solar energy into electrical energy in the form of a direct current (DC). One part generates solar power, i.e., a solar cell that is about 10-15 cm squared. This component converts energy from sunlight into electrical energy [34]. The solar cell is a vital component that is generally made of semi-conductor material [35]. Electric power generated by a solar cell is so small that several solar cells must be combined to form a unit of the component, and this unit is called a module.

According to Sihombing and Kasim [6], the operation of the solar cell maximum depends on the following:

1. ambient air temperature

2. solar radiation (insolation)

3. wind speed

4. Earth's atmosphere

5. panel orientation or PV array

6. the position of the solar cell (array) with respect to the angle of orientation of the sun (tilt angle)

- Lamps

Lamps are part of solar-based street lighting and serve as the lighting output. The application of the lamp type varies depending on the needs of the user. Each lamp has a light pollution based on their type [36-38]. These types are as follows:

1. Sodium Lamps

Sodium lamps have an efficacy of 50-90 lumens/watt with a warm color temperature. This type has a lamp life of $24,000 \mathrm{~h}$. It contains $1-6 \mathrm{mg}$ of sodium and $20 \mathrm{mg}$ of mercury when operating sodium at high temperature and pressure, which can make this lamp reactive [39]. This lamp is out of date and no longer recommended for street lighting.

2. Mercury Lights 
Mercury vapor lamps have a low efficacy of 30-65 lumens/watt, and this characteristic causes the lamp to emit a pale green light. These lamps are widely used as garden or street lighting lamps because of their high life span that can reach 16,000 to 24,000 h [40]. Like sodium lamps, mercury lamps are out of date and no longer recommended for street lighting.

3. LED Lights

LEDs—light emitting diodes-are electronic components made of a semi-conductor type diode material that produces light. The light present in an LED lamp is electromagnetic energy emitted in the visible part of the spectrum [41].

The intensity distribution curve, the luminaire classification system, and an iso-illuminate plot for LED $120 \mathrm{~V}$ is shown in Figures 1-3 below [42].

- $\quad$ Street Lighting Poles

The pole is the foundation of solar-based street lighting. Based on the shape, the pole is one of two types: single pole or double-arm pole. A solar-based street lighting pole needs to be adjusted to road conditions. Related to the height of the solar-based street lighting pole, the wattage of the lamp needs to be assessed, as the amount of lighting can affect the size of the irreversible area [3]. A solar-based street lighting pole could have a height ranging from 5 to $14 \mathrm{~m}$. Moreover, the distance between poles varies from 15 to $40 \mathrm{~m}$. The distance between poles depends on the height of the pole, the type of lamp, and the required light (brightness).

- Battery Panel Boxes for Solar-Energy-Based Street Lighting

The battery panel box is the power center for solar-based street lighting, and consists of a solar charge controller, a terminal block (circuit), a battery management system (BMS), and a battery $[43,44]$. Each of these components has its function in the operation of a solar-based street lighting system. The solar charge controller is an electronic device used to control the direct current that charges the battery. The solar charge controller prevents the battery from overcharging (i.e., from excess charging if the battery is full) and controls the excess voltage from the solar panel/solar cell, as excess voltage and charging will reduce battery life.

Based on field study information conducted by Mardikaningsih et al. [45-47] at Nipress, a company that uses lithium batteries for energy storage, and based on other previous research [48], the general specifications for solar-based street lighting batteries are as follows:

1. The lithium battery capacity for lighting is 3.3 Volts and $30 \mathrm{Ah}$.

2. Battery life follows the Ah of the product that uses the battery power; e.g., if a product requires $10 \mathrm{~A}$ of power, then the battery power can last for $3 \mathrm{~h}$, (ex. 30/10).

3. The battery charge time is also adjusted to the amperage of the battery. If a battery has $30 \mathrm{Ah}$ of power and $5 \mathrm{~A}$ of given electric power, then the time required for charging the battery is $6 \mathrm{~h}$.

4. One lithium battery for street lighting consists of lithium and Li-on with a 30 pcs cell, where a cell's capacity is $1 \mathrm{Ah}$.

5. One cell consists of copper with paste (-) \& aluminum foil with paste (+).

6. There are 30 cells arranged in parallel in one pack of lithium batteries.

7. The battery panel box package consists of eight lithium batteries with a capacity of 3.3 Volts and $30 \mathrm{Ah}$, and is composed of four longitudinal batteries and two parallel copper (gold) and aluminum (silver) batteries. 


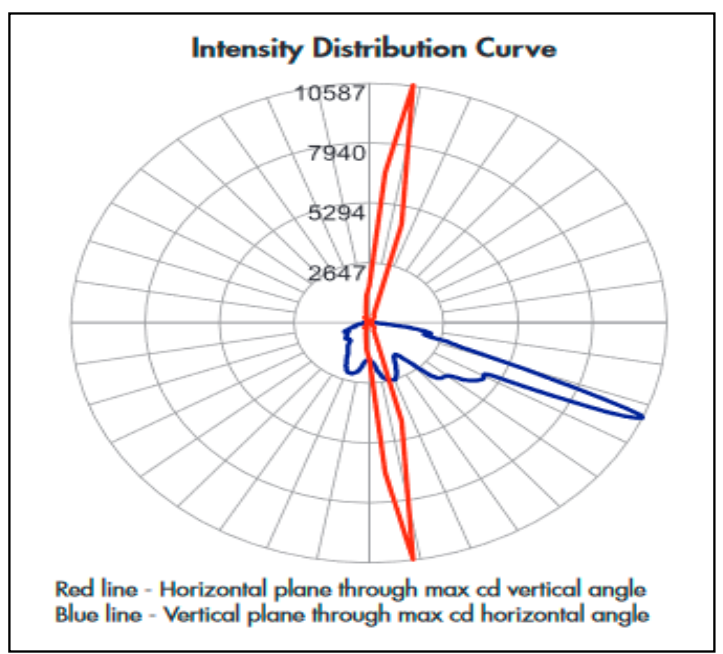

Figure 1. The intensity distribution curve of LEDs.

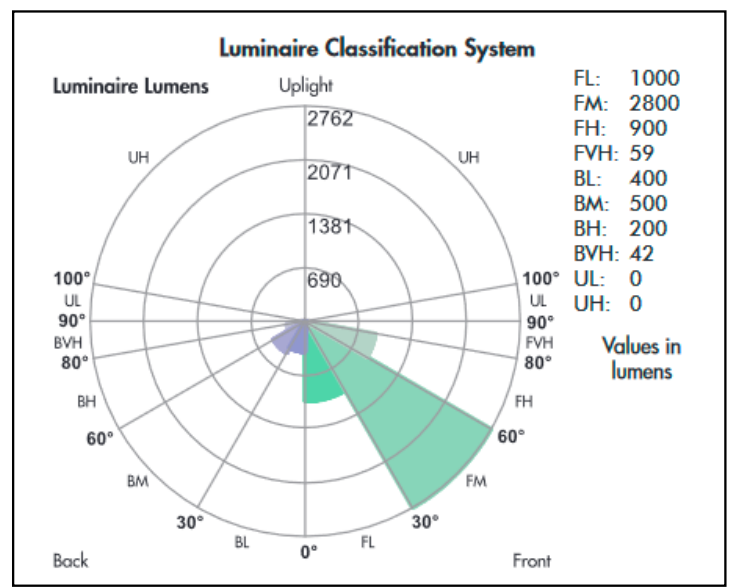

Figure 2. The luminaire classification system of LEDs.

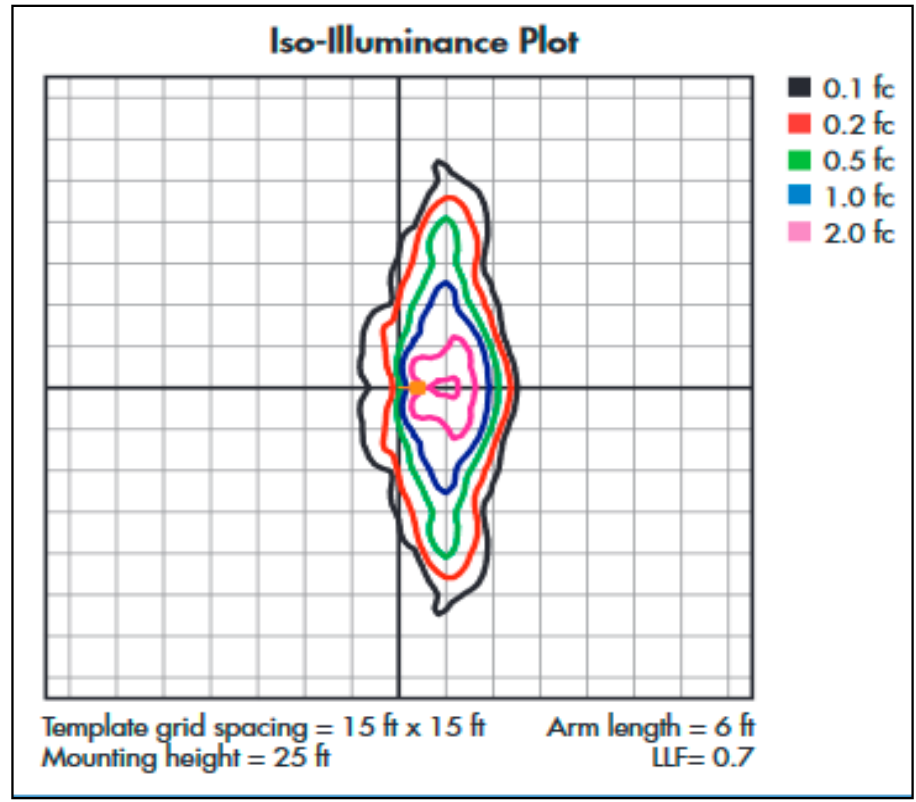

Figure 3. An iso-illuminate plot of LEDs. 


\subsection{The Planning and Design of Solar Street Lighting}

Standards must be followed to construct solar-based street lighting. The standard is intended to ensure safe and optimal performance. In Indonesia, the predefined standards related to public road lighting are described by the NSI (NSI 7391:2008) [3]. The standard components of public street lighting can be seen in Table 1 below.

Table 1. Public street lighting lamp type characteristics based on usage.

\begin{tabular}{|c|c|c|c|c|c|}
\hline Lamp Type & $\begin{array}{c}\text { Average } \\
\text { Efficiency } \\
\text { (Lumen/Watt) }\end{array}$ & $\begin{array}{l}\text { Average Light } \\
\text { Hours (Hour) }\end{array}$ & Power (Watt) & $\begin{array}{l}\text { Effect on the } \\
\text { Color of the } \\
\text { Object }\end{array}$ & Information \\
\hline $\begin{array}{l}\text { Low-pressure } \\
\text { fluorescent } \\
\text { tube lamp }\end{array}$ & $60-70$ & $8000-10,000$ & $18-20 ; 36-40$ & Moderate & $\begin{array}{l}\text { For collector and local roads; } \\
\text { efficiency is quite high but } \\
\text { short-lived; still used for } \\
\text { limited utilization }\end{array}$ \\
\hline $\begin{array}{l}\text { High-pressure } \\
\text { mercury gas } \\
\text { lamp (MBF/U) }\end{array}$ & $50-55$ & $16,000-24,000$ & $\begin{array}{l}\text { 125; 250; 400; } \\
\quad 700\end{array}$ & Moderate & $\begin{array}{l}\text { For collector, local, } \\
\text { and intersection roads; low } \\
\text { efficiency, long life, and small } \\
\text { lamp size; can be used in a } \\
\text { limited way }\end{array}$ \\
\hline $\begin{array}{l}\text { Low-pressure } \\
\text { sodium gas } \\
\text { lamp (SOX) }\end{array}$ & 100-200 & $8000-10,000$ & $90 ; 180$ & Very bad & $\begin{array}{l}\text { For collector, local, } \\
\text { and intersection roads, } \\
\text { crossings, tunnels, and rest } \\
\text { areas; very high efficiency, } \\
\text { a long enough life, and a large } \\
\text { lamp size; thus, it is difficult to } \\
\text { control the light, and the light is } \\
\text { poor because of the yellow color; } \\
\text { recommended for use because } \\
\text { of its high efficiency }\end{array}$ \\
\hline $\begin{array}{l}\text { High-pressure } \\
\text { sodium gas } \\
\text { lamp (SON) }\end{array}$ & 110 & $12,000-20,000$ & $150 ; 250 ; 400$ & Bad & $\begin{array}{l}\text { For highways, arteries, collector } \\
\text { roads, large intersections, } \\
\text { and interchanges; high } \\
\text { efficiency, a very long life, and a } \\
\text { small lamp size; thus, it is easy } \\
\text { to control the light; very good } \\
\text { and highly recommended } \\
\text { for use }\end{array}$ \\
\hline
\end{tabular}

In designing solar-based street lighting, the energy requirement, the photovoltaic area coverage, and the operational cost need to be assessed. This serves to determine the amount of energy and specification that must be delivered; thus, it can provide the components required to be employed. In addition, the costs of installation, operation, and maintenance need to be calculated. Thus, the level of the financial feasibility of the application of solar street lighting can be measured.

a. Total Lamp Power

Total lamp power can be formulated as follows:

$$
P \text { total }=P \times n
$$

where

$P$ total $=$ total lamp power $(\mathrm{W})$;

$P=$ lighting power $(\mathrm{W})$;

$n=$ number of lights.

b. Lamp Power Every Month 
The power of each month can be formulated by

$$
P \text { month }=P \text { total } \times t
$$

where

$P$ month = light power per month (kWh/month);

$P$ total $=$ total light power;

$t=$ time (hour/month).

c. Energy Cost

The energy usage cost incurred each month can be formulated as follows [5]:

$$
M=U \times P \text { month }
$$

where

$M=$ monthly usage fee (IDR/month);

$U=$ rate of usage fee per month (IDR/kWh);

$P$ month $=$ the total power of the lamp each month (W).

d. PV Area Calculation

Power (watt peak), which can be generated by a solar-based street lighting system in generating electrical energy, can be calculated by the equation refer to reference [49] below,

$E_{\mathrm{L}}=$ energy consumption $(\mathrm{kWh} /$ day $)$;

$G_{\mathrm{av}}=$ insolation of solar daily light $\left(\mathrm{kWh} / \mathrm{m}^{2}\right)$;

$\eta_{\mathrm{pv}}=$ solar panel efficiency (\%);

$\eta_{\text {out }}=$ overall system efficiency of the solar panel (battery and inverter);

$P V$ area $=$ solar panel area $\left(\mathrm{m}^{2}\right)$.

From the calculation of the $P V$ area above, then the power raised by solar-based street lighting (watt peak) can be calculated by the formula below [44]:

$$
P \text { peak power }=P V \text { area } \times P S I \times \eta_{\mathrm{pv}}
$$

where

$P$ peak power $=$ power generated $(w p)$;

$P S I=$ peak solar insolation $\left(1000 \mathrm{w} / \mathrm{m}^{2}\right)$.

Furthermore, to obtain the number of solar panels required can be calculated by the following formula:

$$
\text { ( } P \text { weak power)/PMPP }
$$

where

$P M P P=$ maximum output power (output) from one solar panel (wp).

\subsection{Investment Requirement for Solar-Based Street Lighting}

The construction of solar-based street lighting will require a thorough estimation of investment. Investment in a project generally requires substantial funds and will affect investors in the long run [50]. 
Therefore, meticulous investment planning is required to avoid unprofitable investing projects [51]. Overall, the scope of aspects reviewed in a feasibility study include the following:

- Technical aspects

A technical aspect is reviewed to determine the feasibility level of the project from a technical point of view. Evaluation of technical aspects includes product description, determination of the economic production capacity of the project, production processes undertaken, the raw material inventory, the amount of labor, the use of machinery, and equipment. This review is an attempt to answer whether the project is reliable, safe, and accountable [52].

- Financial aspects

The financial aspect is an analysis from the point of view of the project or financial manager. In this case, the analysis of the financial aspects is related to solar-based street lighting components that require funding and to estimated revenue/earnings. It is examined especially by a comparison between money spent and the revenue/earnings of the project [53]. The purpose of financial analysis is to determine whether a project is financially viable, i.e., whether the project is capable of producing a proper return on invested capital.

The method used to measure investment feasibility in this research is benefit-cost analysis. Benefit-cost analysis is a common analytic method to evaluate government or company projects. This analysis is a practical way of estimating project benefits, for which a review is necessarily long and wide [54]. In other words, analysis and evaluation of various audits require a relevant view of the costs and benefits that are involved [55]. The cost-benefit analysis looks at the ratio between the benefits of a project to the general public against the costs incurred by government. Mathematically, it can be explained using the formula below:

$$
B C \text { Ratio }=\frac{\text { equivalent benefits }}{\text { equivalent expenditure }}
$$

where $B C$ Ratio is the benefit-cost ratio $(B C R)$, equivalent benefits are all benefits that have been reduced by negative impacts, expressed as a monetary value, and equivalent expenditures are all costs after deducting the magnitude savings that can be obtained by a project sponsor, in this case, the government.

The costs to be borne by a project are actually composed of the cost of investment and the operating and maintenance costs. In the analysis, the cost and benefits of operating expenses are included as negative benefits [56]; thus, the above formula can be modified as follows:

$$
B C \text { Ratio }=\frac{\text { (net benefit for public) }-(\text { operational and maintenance })}{\text { net investment }}
$$

From the above equation, the feasibility of an investment from a business can be determined. If the value of $B C R=>1$, then running the project is feasible. If $B C R<1$, then it is not feasible. If all $>1$, then one should seek the largest $B C R$ value. If all $<1$, then one should seek the smallest $B C R$ value.

To assess the feasibility of solar-energy-based street lighting, it is necessary to employ certain methods to obtain accurate analysis results; thus, such methods can be applied as a reference for investment. In order to facilitate this analysis, the research methods have been divided into several stages to provide a progressive analysis related to the deployment of street lighting in this case study. The methodology of the case study in this research can be seen in Figure 4 below. 


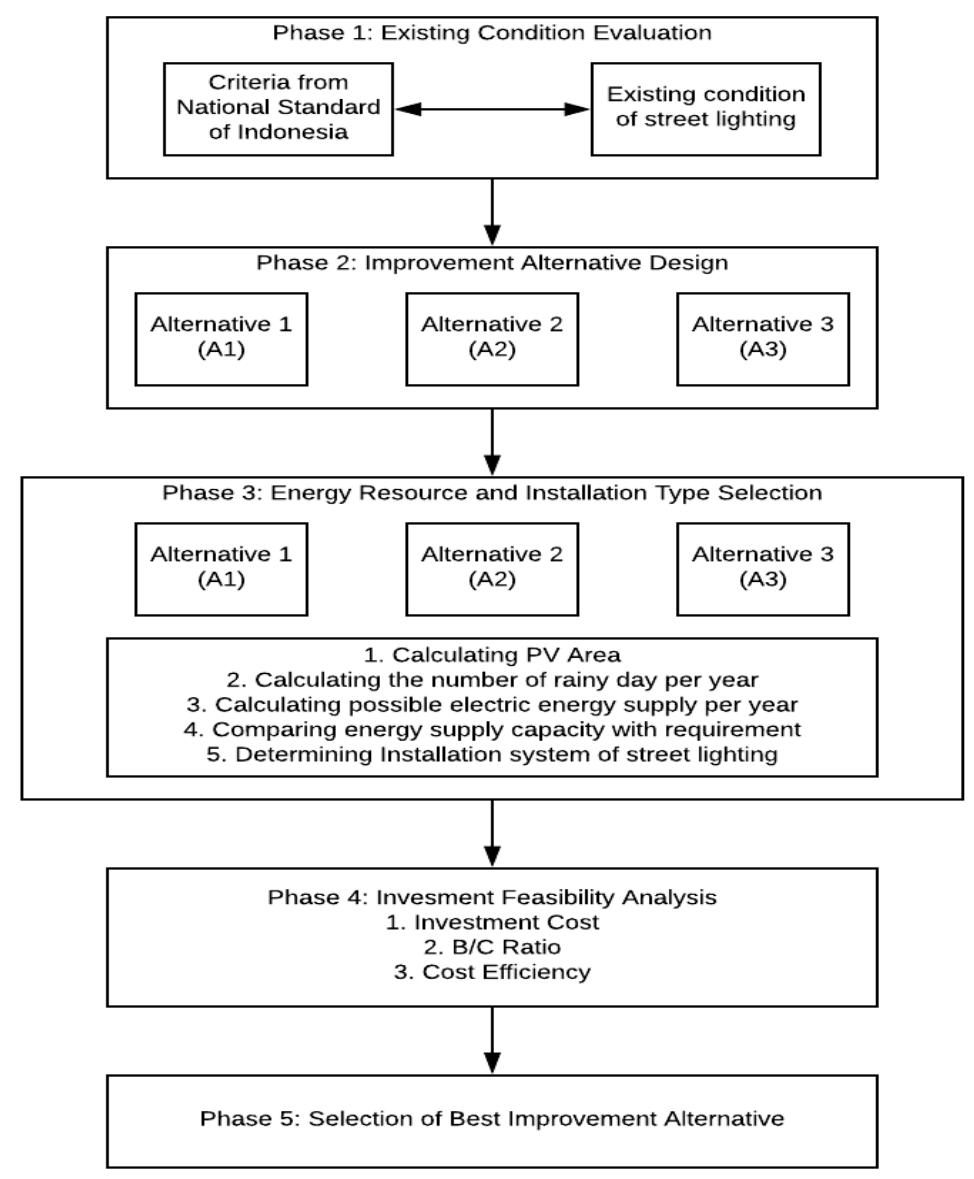

Figure 4. Methodology.

Based on Figure 4, the analysis method in this article consists of five phases.

- Phase 1: Existing Condition Evaluation

This evaluation is conducted in order to assess the utility, performance, and judgments related to the quality of a particular case $[57,58]$. In this research, the street lighting is evaluated by examining the existing condition of the lighting system on the street around the faculty by comparing them with the NSI criteria. The comparison itself is made to explore performance and quality, i.e., whether the current existing light is better or lesser than the NSI. Moreover, the evaluation is assessed using DIALux 4.12 software.

- $\quad$ Phase 2: Improvement of Alternative Design

The evaluation process in Phase 1 results from three alternative designs. The first alternative (A1) replaces all present lighting systems. The second alternative (A2) proposes the repair of pole height and/or lamp power or the installation of new lighting poles. Grouping street lighting based on pole height is the third alternative (A3). The three options are simulated by DIALux 4.12 to check whether the new lighting system is compatible, and a minimum percentage of black area is determined.

- $\quad$ Phase 3: Energy Resource and Installation Type Selection

Next, the energy resource of the lighting is determined by a set of calculations, involving PV area, annual rainy day, energy supply capacity, and energy requirement per year. The resource can be fully conventional energy, fully solar energy (off-grid), or a combination of solar and conventional energy (on-grid). Next, the system installation type is chosen, i.e., stand-alone or centralized. The energy resource and installation type are determined for all respective alternatives. 
- $\quad$ Phase 4: Investment Feasibility Analysis

Besides technical assessment, investment feasibility analysis needs to be conducted in order to determine whether the proposed improvement is economically feasible and competitive [59-61]. The benefit-cost ratio ( $B C$ Ratio; $B C R$ ) is used to examine the economic feasibility of the system. More than one alternative might be considered technically and economically feasible, but only one is chosen.

- Phase 5: Best Improvement Alternative Selection

If analysis has been robustly conducted, considering technical and investment feasibility, the best alternative will be selected as the primary street lighting system.

\section{Results}

\subsection{Evaluation of Existing Street Lighting System}

The evaluation process began by assessing several aspects of 17 lighting points spread around the faculty (Figure 5), including pole height, distance between poles, illumination level, and lamp power. All of the data were processed by DIALux 4.12 software to reveal light distribution. Light distribution is shown in Figure 6.

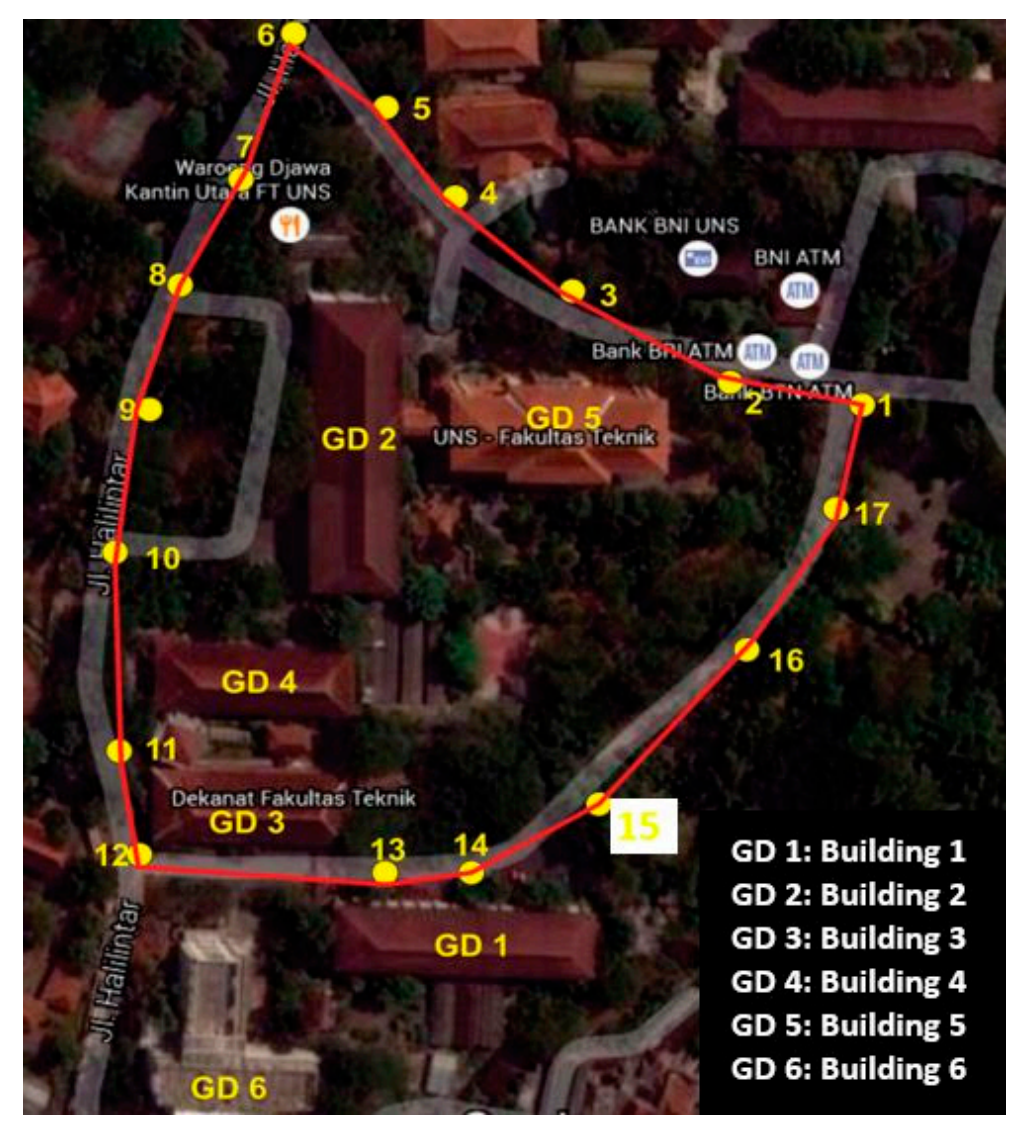

Figure 5. Street lighting location map.

The result was compared to the national standards of street lighting for an evaluation summary. According to the evaluation, the current condition results in $64.7 \%$ black area, which increases vulnerability to accidents and crime incidents. Hence, an improvement regarding street lighting design is required. 

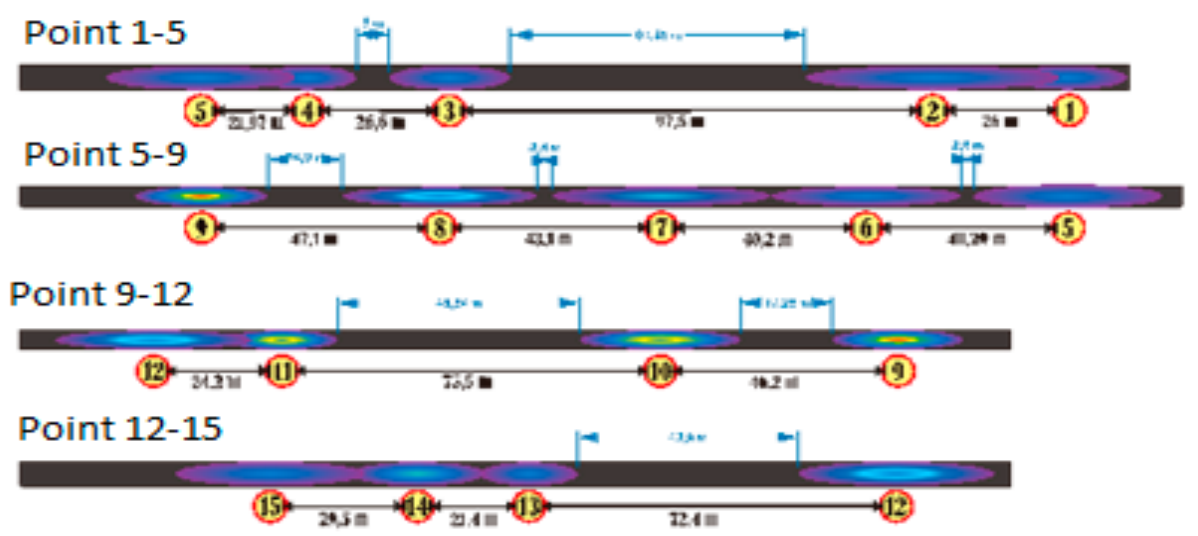

Point 15-17-1

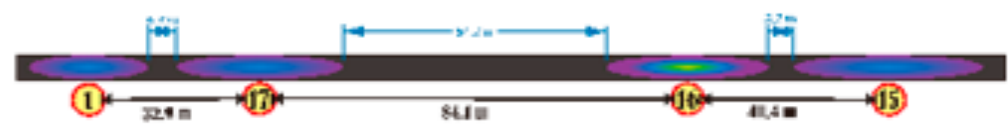

Figure 6. Evaluation results of the existing system.

\subsection{Design of New Street Lighting System Structure}

We present three alternatives to the current street lighting system. The first alternative (A1) replaces all present lighting systems. The second alternative (A2) proposes the repair of pole height and lamp power or installing new lighting poles. Grouping street lighting based on pole height is the third alternative (A3). In the decision process, several factors need to be considered, such as pole height, distance between poles, street width, and lamp power and type. LED lamps are used in this system due to the lower amount of power consumed to emit the same amount of lumens as mercury lamps [58]. These factors were processed in the lighting simulation software DIALux. The DIALux results show whether the alternatives are feasible or not.

According to the software, the A1 option provides three alternatives to the lamp structure regarding the power, pole height, and distance between poles. The best lamp structure is determined based on cost efficiency and illumination level assessment. LED lamps with 50 watts of power, a $6 \mathrm{~m}$ height, and a $25 \mathrm{~m}$ distance to the adjacent lamp pole are the best option. The A1 option is technically feasible because the simulation shows no black area on the analyzed streets. The simulation result of the A1 option can be seen in Table 2 and Figure 7.

Table 2. Simulation results of Alternative 1.

\begin{tabular}{ccccccccc}
\hline Lamp Power & $\begin{array}{c}\text { Pole Height } \\
(\mathbf{m})\end{array}$ & $\begin{array}{c}\text { Distance } \\
\text { between } \\
\text { Poles }(\mathbf{m})\end{array}$ & $\begin{array}{c}\text { Pole Length } \\
(\mathbf{m})\end{array}$ & $\begin{array}{c}\text { Pole } \\
\text { Angle }\left({ }^{(\mathbf{})}\right.\end{array}$ & $\mathbf{c d} / \mathbf{m}^{\mathbf{2}}$ & U0 & U1 & $\begin{array}{c}\text { TI } \\
(\%)\end{array}$ \\
\hline LED 40 W & 5 & 18 & 2.8 & 6 & 0.73 & 0.42 & 0.78 & 15 \\
LED 50 W & 6 & 25 & 2.8 & 6 & 0.75 & 0.43 & 0.73 & 15 \\
LED 80 W & 6 & 29 & 2.8 & 2 & 0.7 & 0.46 & 0.5 & 14 \\
\hline
\end{tabular}

The A2 option was simulated in another way. Calculating the distance between black areas is the first step, so as to improve either the lamp power or the pole's height. A new lighting spot is added only if the two previous treatments are unsuccessful. The simulation result shows that the A2 option needs to replace two lamp spots, Points 3 and 4, with lamps with a higher power. As many as 14 lamps would be required. Thus, the lighting system in the A2 option is feasible because the black area is diminished. Table 3 and Figure 8 elaborate the simulation results of Alternative 2 in more detail. 


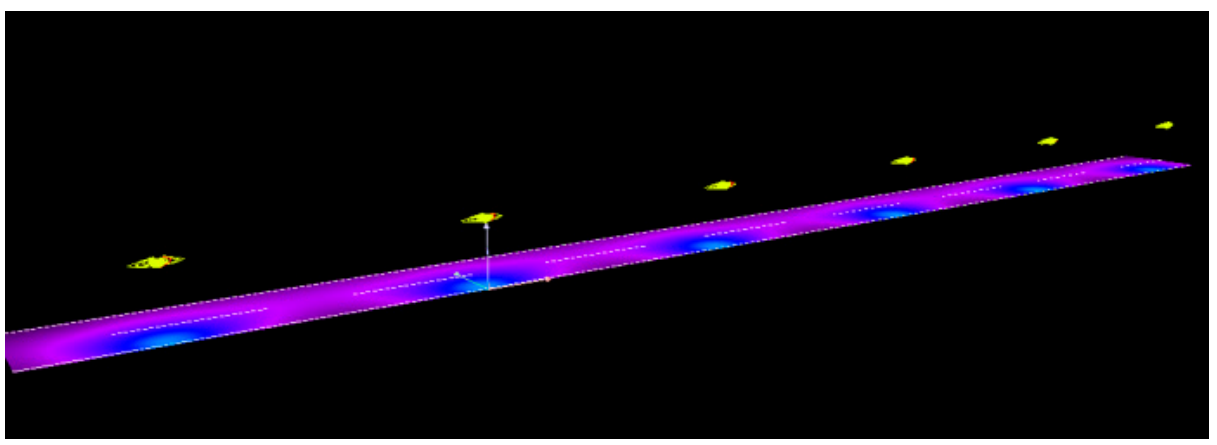

Figure 7. Illumination simulation of Alternative 1.

Table 3. Simulation results of Alternative 2.

\begin{tabular}{ccccccc}
\hline \multirow{2}{*}{ Object } & Option & $\begin{array}{c}\text { Lamp } \\
\text { Power (W) }\end{array}$ & $\begin{array}{c}\text { Poles } \\
\text { Height }(\mathbf{m})\end{array}$ & $\begin{array}{c}\text { Distance } \\
\text { between } \\
\text { Poles } \mathbf{( m )}\end{array}$ & $\begin{array}{c}\text { Poles } \\
\text { Length }(\mathbf{m})\end{array}$ & $\begin{array}{c}\text { Illumination } \\
\left(\mathbf{c d} / \mathbf{m}^{2}\right)\end{array}$ \\
\hline \multirow{2}{*}{ Points 2-3 } & Add Point 2a & LED 50 W & 6.0 & 40.135 & 2.80 & 0.80 \\
& Add Point 2b & LED 50 W & 6.0 & 30.205 & 2.80 & 0.80 \\
\hline \multirow{2}{*}{ Points 3-4 } & Change Lamp Power T3 & LED 50 W & 6.2 & 26.600 & 1.90 & 0.73 \\
& Change Lamp Power T4 & LED 50 W & 6.1 & 21.370 & 1.60 & 0.73 \\
\hline Points 5-6 & Add Point 5a & LED 40 W & 5.0 & 20.150 & 2.80 & 1.82 \\
\hline Points 7-8 & Add Point 7a & LED 40 W & 5.0 & 21.550 & 2.80 & 1.62 \\
\hline Points 8-9 & Add Point 8a & LED 40 W & 5.0 & 25.584 & 2.80 & 0.81 \\
\hline Points 9-10 & Add Point 9a & LED 40 W & 5.0 & 23.100 & 2.80 & 0.81 \\
\hline \multirow{2}{*}{ Points 10-11 } & Add Point 10a & LED 50 W & 6.0 & 29.471 & 2.80 & 0.75 \\
\hline \multirow{2}{*}{ Points 12-13 } & Add Point 10b & LED 50 W & 6.0 & 24.270 & 2.80 & 0.75 \\
\hline Points 15-16 & Add Point 12a & LED 50 W & 5.5 & 30.974 & 2.80 & 0.88 \\
\hline \multirow{2}{*}{ Points 16-17 } & Add Point 12b & LED 50 W & 5.5 & 24.200 & 2.80 & 0.88 \\
\hline Points 17-1 & Add Point 15a & LED 40 W & 5.0 & 20.200 & 2.80 & 1.62 \\
\hline
\end{tabular}

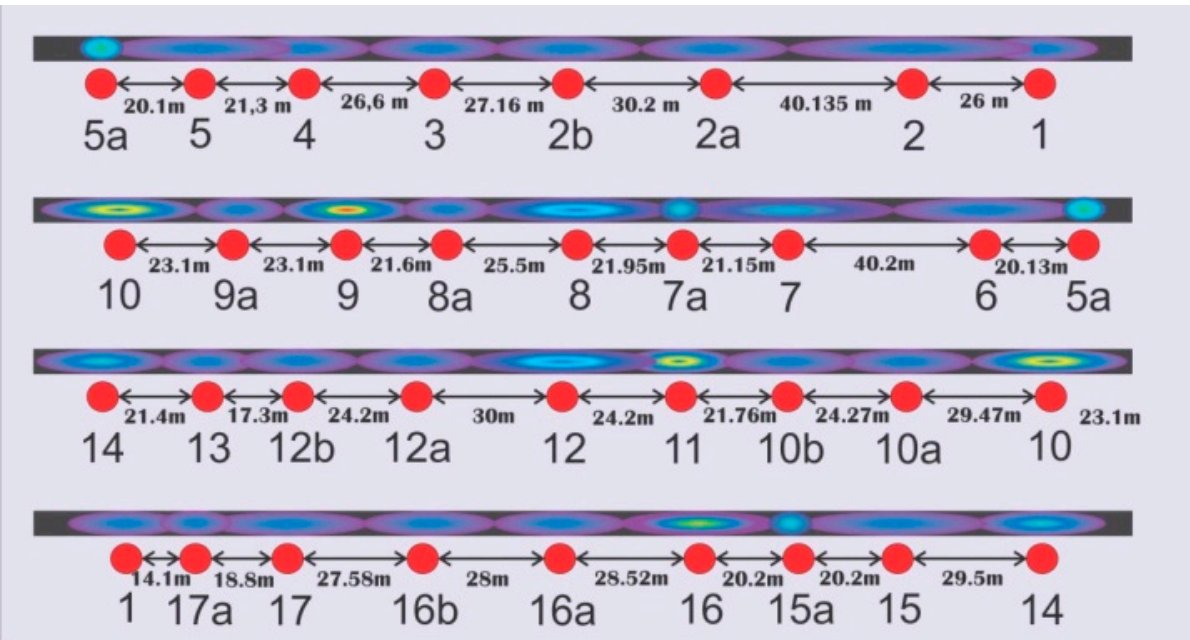

Figure 8. Illumination simulation of Alternative 2.

Unlike A1 and A2, the A3 option groups lighting points based on the pole's height. The simulation has three groups of poles. The first group is for lamps with taller than $6 \mathrm{~m}, 4-6 \mathrm{~m}$ lamp poles are classified into the second group; and the rest of the lamps are grouped in the last group. The black area 
found in areas with lamp poles with a height of less than $4 \mathrm{~m}$ vanishes when lighting points with lamp poles $\geq 4 \mathrm{~m}$ in height are added.

Meanwhile, the other black areas are lightened with 4-5 m lamp poles. Notwithstanding the non-standardized lamp height, poles are kept under the assumption that there are neither heavy vehicles nor buses passing. In addition, there is no black area in the DIALux simulation using the A3 system option, which means it is technically feasible for implementation. The simulation result of A3 is explained in Table 4 and Figure 9 more clearly.

Table 4. Simulation results of Alternative 3.

\begin{tabular}{cccc}
\hline Lighting Point & Poles Height $\mathbf{( m )}$ & Group & Location \\
\hline 1 & 6.3 & Group 1 & In front of Building 5 \\
2 & 7.0 & Group 1 & In front of Building 5 \\
3 & 6.2 & Group 1 & In front of Building 5 \\
4 & 6.1 & Group 1 & In front of Building 5 \\
5 & 6.0 & Group 1 & In front of Building 5 \\
6 & 6.0 & Group 1 & In front of Building 5 \\
7 & 5.1 & Group 2 & In front of Building 2 \\
8 & 4.4 & Group 2 & In front of Building 2 \\
9 & 2.8 & Group 3 & In front of Building 2 \\
10 & 3.5 & Group 3 & In front of Building 2 \\
11 & 3.4 & Group 3 & In front of Building 2 \\
12 & 4.1 & Group 2 & In front of Building 2 \\
13 & 6.7 & Group 1 & In front of Building 5 \\
14 & 4.3 & Group 2 & In front of Building 2 \\
15 & 6.0 & Group 1 & In front of Building 5 \\
16 & 3.6 & Group 3 & In front of Building 2 \\
17 & 5.6 & Group 2 & In front of Building 2 \\
\hline
\end{tabular}

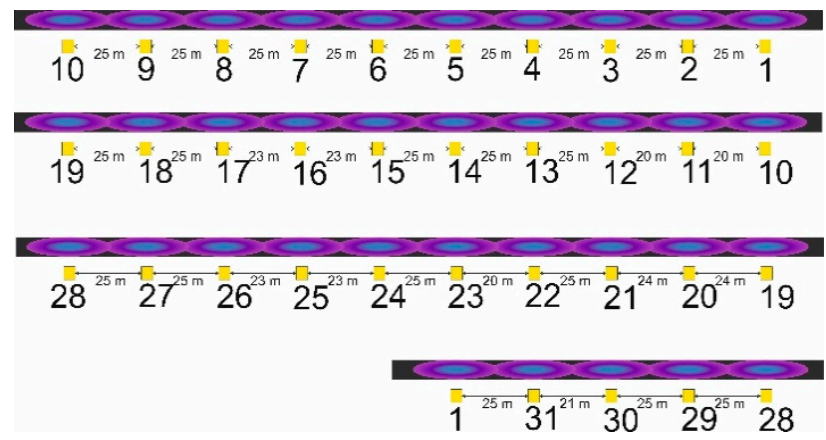

Figure 9. Illumination simulation of Alternative 3.

\subsection{Energy Resource and Installation Type}

Three alternative energy sources are available in designing the new street lighting system: conventional, solar cells (off-grid), and a hybrid of solar and conventional energy (on-grid). In order to decide which source is the best choice for implementation, the PV area needs to be known, which is determined by the equation below [49]. The PV area will provide information regarding the comparison between energy requirement and probable capacity, respectively, for each improvement alternative.

$$
\frac{E_{\mathrm{L}}}{G_{\mathrm{av}} \times \eta_{\mathrm{pv}} \times T C F_{\mathrm{av}} \times \eta_{\mathrm{out}}}=\text { PV Area }
$$

where

$E_{\mathrm{L}}=$ energy consumption (kWh/day);

$G_{\mathrm{av}}=$ daily sunlight insolation $\left(\mathrm{kWh} / \mathrm{m}^{2}\right)$; 
$\eta_{\mathrm{pv}}=$ solar panel efficiency $(\%)$;

$\eta_{\text {out }}=$ total efficiency of the solar panel (battery and inverter);

$P V$ Area $=$ solar panel area $\left(\mathrm{m}^{2}\right)$.

The first step in calculating the $P V$ area is determining the total energy needs for daily street lighting operation. A1 and A2 each require $19.07 \mathrm{kWh}$; A3 requires $18.95 \mathrm{kWh}$ for daily operation. However, the PV calculation loss factor value and the lamp operational duration need to be considered. The loss factor value is the amount of generated energy that is lost due to conversion from electric to heat energy (loss energy). The loss factor value here was $1.26 \mathrm{kWh}$, while the operation time was assumed to be $12 \mathrm{~h}$.

$\mathrm{G}_{\mathrm{av}}$ is the daily lighting insolation value, which is considered from 6:00 a.m. to 6:00 p.m. Lighting insolation is the radiation energy coming from the sun to the earth's surface. Surakarta City gains $3.3 \mathrm{kWh} / \mathrm{m}^{2} /$ day of sun insolation [45].

The other considered variables are $\eta p v$ and $\eta$ out, which stand for the solar cell panel efficiency, which is as high as $17 \%$ [42], and the component efficiency, which both complement solar-panel-based street lighting systems. The system is equipped with a battery, an inverter, and a controller, which means $\eta$ out is a multiplication value of those three components, as shown by the equation below. Calculation of $\eta$ out is as follows:

battery inefficiency $=15 \%$;

inverter inefficiency $=10 \%$;

controller inefficiency $=2 \%$.

$$
\eta_{\text {out }}=\eta_{\mathrm{b}} \times \eta_{\mathrm{i}} \times \eta_{\mathrm{c}}=0.85 \times 0.90 \times 0.98=0.7497 .
$$

The optimum temperature in solar panel cell work is $25^{\circ} \mathrm{C}$, yet geographical data from NASA shows that the average temperature of Surakarta City is $27.1^{\circ} \mathrm{C}$ [44]. This condition leads to a power reduction for every temperature rise. The temperature change factor (TCF) value can be calculated by the expression below.

$$
\begin{gathered}
P_{\text {when } t \text { is rising }{ }^{\circ} \mathrm{C}}=0.5 \% /{ }^{\circ} \mathrm{C} \times P_{\mathrm{MPP}} \times \text { rising amount of } T\left({ }^{\circ} \mathrm{C}\right) \\
P_{\mathrm{MPP} \text { when } 2.01{ }^{\circ} \mathrm{C}}=0.5 \% /{ }^{\circ} \mathrm{C} \times 50 \mathrm{~W} \times 2.1{ }^{\circ} \mathrm{C}=0.525 \mathrm{~W} \\
P_{\mathrm{MPP} \text { when rising } t^{\circ} \mathrm{C}}=P_{\mathrm{MPP}}-P_{\text {when rising }}{ }^{\circ} \mathrm{C} \\
P_{\mathrm{MPP} \text { when } t}=27.1^{\circ} \mathrm{C}=P_{\mathrm{MPP}}-P_{\text {when rising }}{ }^{\circ} \mathrm{C}=50-0.525 \mathrm{~W}=49.475 .
\end{gathered}
$$

Thus,

$$
\mathrm{TCF}=P_{\text {MPPwhen rising } t{ }^{\circ} \mathrm{C}} / P_{\mathrm{MPP}}=\frac{49.475}{50}=0.9895 .
$$

If the value of $G_{\mathrm{av}}, \eta_{\mathrm{pv}}, T C F$, and $\eta_{\mathrm{out}}$ are distributed into the PV area function, the possible produced energy capacity can be found. The number of rainy days then needs to be determined. A rainy day calculation is required since Indonesia has two seasons-a rainy and a dry season - and it is feared that the rainy season is not able to support the system and produce sufficient energy. Rainy days in Surakarta are projected to be 63 days annually [62]. A comparison between energy requirements and the capacity in a year can thus be determined.

Based on the calculation result, it can be seen in Figure 10 that the energy produced by solar cells cannot satisfy the energy requirement of the new street lighting system. Hence, a grid system is considered most suitable for the implementation of the new street lighting system. A hybrid of solar cells as main energy generators and conventional energy sources can maintain the street lighting system well operated when there is a lack of solar power. 


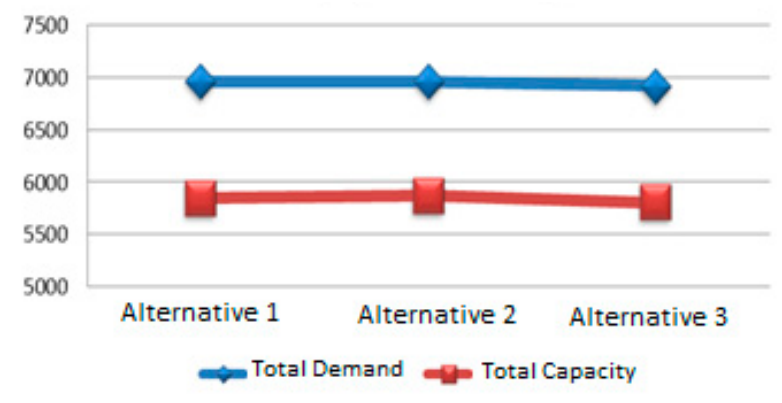

Figure 10. Comparison of alternatives.

The final step in designing a new street lighting system is a selection of the installation type. There are two installation types known for solar-based street lighting systems: "stand-alone" and centralized installation. The stand-alone type is considered unsuitable based on the condition used in this study. This requires poles $6 \mathrm{~m}$ or more in height, whereas in the new proposed system, there are several poles that are less than $6 \mathrm{~m}$. Moreover, the large number of huge trees around the street lighting system location makes it difficult to install a $6 \mathrm{~m}$ pole without cutting off branches or even cutting down the trees. It is difficult to receive permission to cut off branches or cut down trees; the campus slogan indicates it as being "a green campus." Therefore, a centralized type based on an electric panel location is most suitable for implementation in this context.

\section{Discussion}

Economic analysis of the new proposed technology in the street lighting system is required to determine whether the alternatives are economically feasible or not. In this paper, benefit-cost analysis is used to examine the feasibility of the new street lighting system. Benefit-cost analysis is very common in evaluations of government projects. It examines the ratio between the benefit of a project to the public community and government expenses. This analysis practically estimates the beneficial value of a particular project relative to the investment cost, and this is required for long-period assessments. In other words, it is urgent that any cost and benefit gained from the project are evaluated and analyzed from many relevant points of view [51].

Any investment cost for a solar-based street lighting system needs to be known before the analysis is conducted. Investment costs consistent of component, installation, and delivery costs. The amount of investment required for the respective alternative is shown in Table 5. Component replacement cost and operational and maintenance costs are calculated afterward, and it is assumed to be as many as $1-2 \%$ of the total investment cost [53].

Table 5. Total investment.

\begin{tabular}{cc}
\hline Alternative & Investment Cost \\
\hline A1 & IDR $560,176,000$ \\
A2 & IDR $621,437,620$ \\
A3 & IDR $638,091,620$ \\
\hline
\end{tabular}

Next, the operation and maintenance cost of the existing street lighting system is calculated to estimate benefit-cost value in implementing a solar-based street lighting system. The operational and maintenance cost of the current system is known to be as high as IDR 33,744,529. Estimation of the benefit-cost ratio is explained mathematically by this equation. The value of the benefit-cost ratio (BC Ratio) for the respective alternative is shown in Table 6. According to Table 6, it can be seen that all 
alternatives possess a $B C$ Ratio of more than 1 , which means that investment for all three alternatives can be feasibly implemented, respectively.

$$
B C \text { Ratio }=\frac{\text { netto bene fit for public }- \text { operational \& maintenance cost }}{\text { project investment cost }}
$$

$B C$ Ratio $\geq 1 \rightarrow$ investment is accepted;

$B C$ Ratio $<1 \rightarrow$ investment is rejected.

Table 6. Benefit-cost ratio (BC Ratio).

\begin{tabular}{cc}
\hline Alternative & BC Ratio \\
\hline Alternative 1 & 1.02 \\
Alternative 2 & 1.06 \\
Alternative 3 & 1.04 \\
\hline
\end{tabular}

After the $B C$ Ratios of all alternatives are determined, their efficiency also needs to be discovered. The efficiency value is a comparison between the cost of the street lighting system using solar-cell power and a conventional power source. Table 7 illustrates the cost efficiency for three respective proposals. It is clear in Table 7 that the street lighting system using a solar-based energy source is more efficient than the conventional one.

Table 7. Result of technical and economic assessment.

\begin{tabular}{ccccc}
\hline Option & Technical Assessment & Investment Cost & BC Ratio & Cost Efficiency \\
\hline A1 & Feasible & IDR 560,176,000 & 1.02 & $2 \%$ \\
A2 & Feasible & IDR 621,437,620 & 1.06 & $9 \%$ \\
A3 & Feasible & IDR 638,091,620 & 1.04 & $7 \%$ \\
\hline
\end{tabular}

\section{Best Alternative Decision}

Technical and economic assessments that have been done in previous steps are a primary consideration in deciding the best implementation alternative. A comparison of three alternatives regarding technical analysis, total investment cost, BC Ratio, and cost efficiency is shown in Table 7.

The first step in deciding the best alternative is to consider a technical assessment. If there is more than one alternative that is technically feasible, then the alternative with the highest $B C$ Ratio and cost efficiency will be chosen as optimum for implementation. According to Table 6, all three proposals are technically feasible. However, A2 has the highest $B C$ Ratio and cost efficiency among all three alternatives. Therefore, A2 should be chosen as the new street lighting system to be implemented.

\section{Conclusions}

An evaluation of an existing street lighting system in this case study reveals that the system currently cannot satisfy the standard. The system results in $64.7 \%$ black area, which is not suitable for such a public facility. Hence, an improved design is required to replace the current system with a better one. Three alternatives have been proposed:

- The first alternative (A1) replaces all lighting systems with new components;

- The second alternative (A2) offers a solution by fixing the existing system, and includes higher poles, more lamp power, and the installation of new poles;

- The third alternative (A3) groups poles based on height.

All of the alternatives were simulated using DIALux 4.12-software for lighting simulation-to assess the technical aspect indicated by the absence of black area. The energy source can be a fully 
conventional source, solar power only (off-grid), or a hybrid of conventional and solar sources (on-grid). Moreover, the installation type can be standalone or centralized. According to technical analysis, all three options are technically feasible with an on-grid energy source system and a centralized installation type. Thus, an economic analysis using a benefit-cost analysis needed to be conducted to reveal the best alternatives. Benefit-cost analysis indicates A2 as the best alternative.

A2 has the highest $B C R$ of 1.06 and the highest cost efficiency of $9 \%$ among all three alternatives. In conclusion, an improvement in the existing street lighting system with new technology-a solar cell panel—should be implemented in order to create a better public facility.

Further study can be conducted by considering other aspects such as the environment and the market. The possible hybridization of solar energy with other renewable energy sources is another interesting issue. In terms of more technical aspects, drawing the wiring system of the street lighting system can be the next topic.

Author Contributions: Conceptualization: W.S. and R.Z.; methodology: R.Z. and A.A.; survey: I.S.M.; formal analysis: I.S.M.; writing—original draft preparation: W.S. and I.S.M.; writing-review and editing: W.S. and A.A.; supervision: W.S.; project administration: W.S. All authors have read and agreed to the published version of the manuscript.

Funding: This paper was supported by USAID through Sustainable Higher Education Research Alliances (SHERA) Program-Centre for Collaborative (CCR) National Center for Sustainable Transportation Technology (NCSTT) with grant No. IIE00000078-ITB-1.

Acknowledgments: This research was partially funded by the Indonesian Ministry of Research, Technology, and Higher Education under the WCU program, managed by Institut Teknologi Bandung.

Conflicts of Interest: The authors declare that there is no conflict of interest.

\section{Abbreviations}

$\begin{array}{ll}\text { BC Ratio } & \text { Benefit-Cost Ratio } \\ \text { BMS } & \text { Battery Management System } \\ \text { DC } & \text { Direct Current } \\ \text { IDR } & \text { Indonesian Rupiah } \\ \text { LED } & \text { Light-Emitting Diode } \\ \text { PV } & \text { Photovoltaic } \\ \text { NSI } & \text { Standar Nasional Indonesia or National Standard of Indonesia } \\ \text { TCF } & \text { Temperature Change Factor }\end{array}$

\section{References}

1. Morris, M.; Tosunoglu, S. Comparison of Rechargeable Battery Technologies. In Proceedings of the 2012 ASME Early Career Technical Conference, ASME ECTC, Atlanta, GA, USA, 2-3 November 2012.

2. Atikah, N.; Ghabid, A.H.A.; Sutopo, W.; Purwanto, A.; Nizam, M. Technical Feasibility for Technology Commercialization of Battery Lithium-Ion. In Proceedings of the 2014 International Conference on Electrical Engineering and Computer Science, Bali, Indonesia, 24-25 November 2014; pp. 308-314.

3. Badan Standardisasi Nasional. NSI 7391:2008-Spesifikasi Penerangan Jalan di Kawasan Perkotaan. In National Standard of Indonesia (NSI) No. 73912008; Badan Standardisasi Nasional: Jakarta, Indonesia, 2008; pp. 1-41.

4. Velaga, N.R.; Kumar, A. Techno-economic Evaluation of the Feasibility of a Smart Street Light System: A case study of Rural Indi. Procedia Soc. Behav. Sci. 2012, 62, 1220-1224. [CrossRef]

5. Kusumayogo, E.; Wibawa, U.; Suyono, H. Analisis Teknis Dan Ekonomis Penerapan Penerangan Jalan Umum Solar Cell Untuk Kebutuhan Penerangan Di Jalan Tol Darmo Surabaya. J. Mhs. Tek. Elektro Univ. Brawijaya 2014, 2, 1-6.

6. Sihombing, D.T.B.; Kasim, S.T. Perencanaan Sistem Penerangan Jalan Umum Dan Taman Di Areal Kampus Usu Dengan Menggunakan Teknologi Tenaga Surya (Aplikasi Di Areal Pendopo Dan Lapangan Parkir). Departemen Teknik Elektro Fakultas Teknik Universitas Sumatera Utara. Singuda Ensikom 2013, 3, 118-123. 
7. Jamil, M.; Kirmani, S.; Rizwan, M. Techno-Economic Feasibility Analysis of Solar Photovoltaic Power Generation: A Review. Smart Grid Renew. Energy 2012, 3, 266-274. [CrossRef]

8. Ahmad, G.E. Photovoltaic-powdered rural zone family house in Egypt. Renew. Energy 2002, 26, 379-390. [CrossRef]

9. Al-Salaymeh, A.; Al-Hamamre, Z.; Sharaf, F.; Abdelkader, M.R. Technical and economic assessment of the utilization of photovoltaic systems in residential buildings: The case of Jordan. Energy Convers. Manag. 2010, 51, 1719-1726. [CrossRef]

10. Ramadhan, M.; Naseeb, A. The cost-benefit analysis of implementing a photovoltaic solar system in the state of Kuwait. Renew. Energy 2011, 36, 1272-1276. [CrossRef]

11. Kannan, R.; Leong, K.C.; Osman, R.; Ho, H.K.; Tso, C.P. Life cycle assessment study of solar PV systems: An example of a $2.7 \mathrm{kWp}$ distributed solar PV system in Singapore. Sol. Energy 2006, 80, 555-563. [CrossRef]

12. Reid, G.; Wynn, G. The Future of Solar Power in the United Kingdom. Energies 2015, 8, 7818-7832. [CrossRef]

13. Escolar, A.G.; Martinez, A.C.; Pulido, J.M.G.; Martinez, J.M.G.; Stapic, Z.; Merodio, J.A.M. A Study to Improve the Quality of Street Lighting in Spain. Energies 2015, 8, 976-994. [CrossRef]

14. Cellucci, L.; Burattini, C.; Drakou, D.; Gugliermetti, F.; Bisegna, F.; de Lieto Vollaro, A.; Salata, F.; Golasi, I. Urban lighting project for a small town: Comparing citizens and authority benefits. Sustainability 2015, 7, 14230-14244. [CrossRef]

15. Salata, F.; Golasi, I.; Bombelli, E.; de Lieto Vollaro, E.; Nardecchia, F.; Pagliaro, F.; Gugliermetti, F.; de Lieto Vollaro, A. A case study on economic return on investments for safety and emergency lighting in road tunnels. Sustainability 2015, 7, 9809-9822. [CrossRef]

16. Kacprzak, D.; Tuleasca, I. Daylight Savings Calculation Technique for Smart Buildings. Intell. Control Autom. 2013, 4, 102-107. [CrossRef]

17. Satwiko, P. Pemakaian Perangkat Lunak Dialux Sebagai Alat Bantu Proses Belajar Tata Cahaya. Komposisi 2011, 9, 142-154.

18. Salata, F.; Golasi, I.; Poliziani, A.; Futia, A.; de Lieto Vollaro, E.; Coppi, M.; de Lieto Vollaro, A. Management Optimization of the Luminous Flux Regulation of a Lighting System in Road Tunnels. A First Approach to the Exertion of Predictive Control Systems. Sustainability 2016, 8, 1-17. [CrossRef]

19. Sigalingging, R.; Herak, D. Solar Energy Opportunities for Indonesia Agricultural. In Proceedings of the 6th International Conference on Trends in Agricultural Engineering Journal, Prague, Czech Republic, 7-9 September 2016.

20. World Bank. Solar Resource and Photovoltaic Potential of Indonesia; World Bank Group: Washington, DC, USA, 2017.

21. Kumar, S.; Deshpande, A.; Ho, S.S.; Ku, J.S.; Sarma, S.E. Urban Street Lighting Infrastructure Monitoring Using a Mobile Sensor Platform. IEEE Sens. J. 2016, 16, 4981-4994. [CrossRef]

22. Zanjani, P.N. Monitoring and Remote Sensing of the Street Lighting System Using Computer Vision and Image Processing Techniques for the Purpose of Mechanized Blackouts. In Proceedings of the 19th International Conference on Mechatronics and Machine Vision in Practice (M2VIP12), Auckland, New Zealand, 28-30 November 2012.

23. Sharma, N.K.; Tiwari, P.K.; Sood, Y.R. Solar energy in India: Strategies, policies, perspectives and future potential. Renew. Sustain. Energy Rev. 2012, 16, 933-941. [CrossRef]

24. Popa, M.; Marcu, A. A Solution for Street Lighting in Smart Cities. Carpathian J. Electron 2012, 5, 91-96.

25. Liu, G. Sustainable feasibility of solar photovoltaic powered street lighting systems. Int. J. Electr. Power Energy Syst. 2014, 56, 168-174. [CrossRef]

26. Frering, D.; Brons, J.; Emery, C. Demonstration and Evaluation of Sustainable, Photovoltaic Powered LED Street Lighting. Int. J. Electr. Power Energy Syst. 2014, 56, 168-174.

27. Markvart, T. Solar Cells: Materials, Manufacture and Operation; Elsevier: Amsterdam, The Netherlands, 2013; Volume 53.

28. Lawder, M.T.; Suthar, B.; Northrop, P.W.; De, S.; Hoff, C.M.; Leitermann, O.; Subramanian, V.R. Battery energy storage system (BESS) and battery management system (BMS) for grid-scale applications. Proc. IEEE 2014, 102, 1014-1030. [CrossRef]

29. Espinosa, N.; García-Valverde, R.; Urbina, A.; Krebs, F.C. A life cycle analysis of polymer solar cell modules prepared using roll-to-roll methods under ambient conditions. Sol. Energy Mater. Sol. Cells 2011, 95, 1293-1302. [CrossRef] 
30. Peng, J.; Lu, L.; Yang, H. Review on life cycle assessment of energy payback and greenhouse gas emission of solar photovoltaic systems. Renew. Sustain. Energy Rev. 2013, 19, 255-274. [CrossRef]

31. Li, X.P.; Chen, L.; Chen, M. An Approach of LED Lamp System Lifetime Prediction. In Proceedings of the IEEE International Conference on Quality and Reliability, Bangkok, Thailand, 14-17 September 2011; pp. 110-114.

32. Principi, P.; Fioretti, R. A comparative life cycle assessment of luminaires for general lighting for the office-Compact fluorescent (CFL) vs Light Emitting Diode (LED)—A case study. J. Clean. Prod. 2014, 83, 96-107. [CrossRef]

33. Ali, M.; Orabi, M.; Abdelkarim, E.; Qahouq, J.A.A.; El Aroudi, A. Design and Development of Energy-Free Solar Street LED Light System. In Proceedings of the IEEE PES Conference on Innovative Smart Grid Technologies-Middle East, ISGT Middle East 2011, Jeddah, Saudi Arabia, 17-20 December 2011.

34. Kraemer, D.; Poudel, B.; Feng, H.P.; Caylor, J.C.; Yu, B.; Yan, X.; McEnaney, K. High-performance flat-panel solar thermoelectric generators with high thermal concentration. Nat. Mater. 2011, 10, 532-538. [CrossRef] [PubMed]

35. Mitzi, D.B.; Gunawan, O.; Todorov, T.K.; Wang, K.; Guha, S. The path towards a high-performance solution-processed kesterite solar cell. Sol. Energy Mater. Sol. Cells 2011, 95, 1421-1436. [CrossRef]

36. Brons, J.A.; Bullough, J.D.; Rea, M.S. Outdoor site-lighting performance: A comprehensive and quantitative framework for assessing light pollution. Lighting Res. Technol. 2008, 40, 201-224. [CrossRef]

37. Bierman, A. Will switching to LED outdoor lighting increase sky glow. Lighting Res. Technol. 2012, 44, 449-458. [CrossRef]

38. Fryc, I.; Tabaka, P. Outdoor Areas Lighting with LEDs-The Competition Between Scotopic Efficacy and Light Pollution. Photonics Lett. Pol. 2019, 19, 75-77. [CrossRef]

39. Rodrigues, C.R.B.S.; Almeida, P.S.; Soares, G.M.; Jorge, J.M.; Pinto, D.P.; Braga, H.A.C. An Experimental Comparison between Different Technologies Arising for Public Lighting: LED Luminaires Replacing High Pressure Sodium Lamps. In Proceedings of the ISIE 2011: 2011 IEEE International Symposium on Industrial Electronics, Gdansk, Poland, 27-30 June 2011; pp. 141-146.

40. Hou, X.; Ai, X.; Jiang, X.; Deng, P.; Zheng, C.; Lv, Y. UV light-emitting-diode photochemical mercury vapor generation for atomic fluorescence spectrometry. Analyst 2012, 137, 686-690. [CrossRef]

41. Cheng, C.A.; Chang, C.H.; Chung, T.Y.; Yang, F.L. Design and implementation of a single-stage driver for supplying an LED street-lighting module with power factor corrections. IEEE Trans. Power Electron. 2015, 30, 956-966. [CrossRef]

42. National Lighting Product Information Program. The Objective Source of Lighting Product Information. Streetlights Local Roads 2011, 14, 1-27.

43. Raman, P.; Murali, J.; Sakthivadivel, D.; Vigneswaran, V.S. Opportunities and challenges in setting up solar photovoltaic based microgrids for electrification in rural areas of India. Renew. Sustain. Energy Rev. 2012, 16, 3320-3325. [CrossRef]

44. Leccese, F. Remote-Control System of High Efficiency and Intelligent Street Lighting Using a ZigBee Network of Devices and Sensors. IEEE Trans. Power Deliv. 2013, 28, 21-28. [CrossRef]

45. Mardikaningsih, I.S.; Sutopo, W.; Hisjam, M.; Zakaria, R. Techno-Economic Feasibility Analysis of a Public Street Light with Solar Cell Power. In Proceedings of the International MultiConference of Engineers and Computer Scientists, Hongkong, China, 21-23 March 2017.

46. Mardikaningsih, I.S.; Sutopo, W.; Astuti, R.W. Studi Kasus Analisis Teknis Dan Ekonomis Penerapan Penerangan Jalan Umum Bertenaga Sel Surya. In Proceedings of the Industrial Engineering Conference (IDEC), Surakarta, Indonesia, 9 September 2015; pp. 290-297.

47. Mardikaningsih, I.S.; Sutopo, W.; Zakaria, R.; Nizam, M.; Kadir, E.A. Evaluation and Designing Street Lighting with Solar Cell: A Case Study. In Proceedings of the 2016 2nd International Conference of Industrial, Mechanical, Electrical, and Chemical Engineering, ICIMECE 2016, Yogyakarta, Indonesia, 6-7 October 2016; pp. 186-191.

48. Yudha, C.S.; Muzayanha, S.U.; Widiyandari, H.; Iskandar, F.; Sutopo, W.; Purwanto, A. Synthesis of $\mathrm{LiNi}_{0.85} \mathrm{Co}_{0.14} \mathrm{Al}_{0.01} \mathrm{O}_{2}$ Cathode Material and its Performance in an NCA/Graphite Full-Battery. Energies 2019, 12, 1886. [CrossRef]

49. El-menchawy, A.; Bassioni, H.; Farouk, A. Photovoltaic Systems in Existing Residential Building in Egypt List of Abbreviations. Int. J. Sci. Eng. Res. 2011, 2, 1-11. 
50. Pina, A.; Silva, C.A.; Ferrão, P. High-resolution modeling framework for planning electricity systems with high penetration of renewables. Appl. Energy 2013, 112, 215-223. [CrossRef]

51. Khodaei, A.; Shahidehpour, M.; Wu, L.; Li, Z. Coordination of short-term operation constraints in multi-area expansion planning. IEEE Trans. Power Syst. 2012, 27, 2242-2250. [CrossRef]

52. Kumbaroglu, G.; Madlener, R. Evaluation of economically optimal retrofit investment options for energy savings in buildings. Energy Build. 2012, 49, 327-334. [CrossRef]

53. Gilchrist, S.; Sim, J.; Zakrajsek, E. Uncertainty, Financial Frictions, and Investment Dynamics. SSRN Electron. J. 2014, 1-58. [CrossRef]

54. Posner, E.; Weyl, E.G. Benefit-cost analysis for financial regulation. Am. Econ. Rev. 2013, 103, $393-397$. [CrossRef]

55. Boardman, A.; Greenberg, D.; Vining, A.; Weimer, D. Introduction to cost-benefit analysis. J. Legal Stud. 2000, 29, 837.

56. Adler, M.D. Behavioral Economics, Happiness Surveys, and Public Policy. J. Benefit Cost Anal. 2016, 7, 196-219. [CrossRef]

57. Topno, H. Evaluation of Training and Development: An Analysis of Various Models. J. Bussiness Manag. 2012, 5, 16-22. [CrossRef]

58. Stavropoulou, A.; Kelesi, M. Concepts and methods of evaluation in nursing education-a methodological challenge. Heal. Sci. J. 2012, 6, 11-23.

59. De Santoli, L.; Lo Basso, G.; Bruschi, D. A small scale H2NG production plant in Italy: Techno-economic feasibility analysis and costs associated with carbon avoidance. Int. J. Hydrog. Energy 2014, 39, 6497-6517. [CrossRef]

60. Brown, T.R. A techno-economic review of thermochemical cellulosic biofuel pathways. Bioresour. Technol. 2015, 178, 166-176. [CrossRef]

61. Gan, C.K.; Sapar, A.F.; Mun, Y.C.; Chong, K.E. Techno-economic analysis of LED lighting: A case study in UTeM's faculty building. Procedia Eng. 2013, 53, 208-216. [CrossRef]

62. Rachmadiyanto, A.N.; Dewi, W.S.; Senge, M.; Ariyanto, D.P. Crop water productivity (CWP) with the small farm reservoir (SFR) as supplemental irrigation for cash crop on a rainfed area in Karanganyar Regency, Indonesia. Glob. Adv. Res. J. Agric. Sci. 2014, 3, 158-164. 